\title{
Assessing the Effects of COVID-19 Pandemic Partial Lockdown of Cities on Access to Social Facilities
}

\author{
Wahab Musah-Abdu1 ${ }^{*} \quad$ John Amoah-Nuamah ${ }^{2}$ Lord Ebow Sampson ${ }^{2}$ \\ 1.Department of Planning, Kwame Nkrumah University of science and Technology, PMB KNUST, Kumasi, \\ Ghana \\ 2.Department of Geography and Regional Planning, University of Cape Coast, PMB, Cape Coast, Ghana
}

\begin{abstract}
Social facility is very useful for societal interaction and cohesion. This study was based on review of literature to assess the effects of Novel Coronavirus 2019 Pandemic lockdown of cities on social facility. The study revealed that maternal mortality rate would increase, Christians and Muslims routine of worship as a group has been mileage, whiles people are not able to engage in active exercise to keep fit as a result of the lockdown of the cities. The paper recommend that Government and management of cities should provide mobile clinic for pregnant and patients at house to house. This will help to prevent unforeseen deaths of pregnant women and patients with underlining sickness.
\end{abstract}

Keywords: Covid-19, Lockdown, Social Facility, Cities, Ghana

DOI: $10.7176 / \mathrm{DCS} / 10-6-03$

Publication date: June $30^{\text {th }} 2020$

\section{Introduction}

Coronavirus (COVID-19) outbreak in China is one of the single-stranded, positive-sense enveloped Ribonucleic Acid (RNA) virus subfamily, Orthocoronavirinae, family Coronaviridae, order Nidovirales. In the Midst of these four are usually spread human coronaviruses (HCoV-229E, HCoV-OC43, HCoV-NL63, HCoVHKU1) which cause common cold, Severe Acute Respiratory Syndrome (SARS-CoV), Cough and Sneezing (Owusu et al., 2014; Pfefferle et al., 2009). A novel coronavirus (COVID-19) was identified in Wuhan, China on December 2019 and begun to spread globally and has impact on the world health and economy (Alexandra Peters et al., 2020).

Report by John Hopkins Bloomberg of Public Health University on $9^{\text {th }}$ April, 2020, indicates that globally 1,353,361 confirmed COVID-19 cases (73,639 new) and 79,235 deaths (6,695 new). They further indicated that globally, $5.8 \%$ of the total reported cases have died and assessment is focused greatly by the tome of cases and deaths in Europe and varies by region: Europe: $8.0 \%$ America: 3.0\% Western Pacific: 3.4\% Eastern Mediterranean: 5.3\% South-East Asia: $4.0 \%$ Africa: $4.3 \%$.

According to World Health Organization (WHO) $8^{\text {th }}$ April, 2020 external situation Report 6, Africa countries are seen as countries with few cases, however there are now more than over 7,105 confirmed cases of coronavirus across the continent with 324 deaths and these has led to number of African countries imposing a range of prevention and containment measures against the spread of the pandemic. According to the latest data by the Africa Center for Disease Control on COVID-19 in Africa, the breakdown remains fluid as countries confirm cases as and when it befall. The whole of Africa has rising cases with a handful of countries holding out.

Moreover, the continue spread of the virus to different countries in the world has created more challenges for most government to take unbending decision to curtail the spread of the coronavirus among their citizens. The common measures taking by most governments were the guidelines issued by world health organization (WHO) which includes, social distancing, regular hand wash, covering of nose and quarantine.

However, most countries have added rigid measures such as total lockdown of the entire country or partial lockdown of some major urban towns to prevent people from engaging in business, reduction of human traffic in the cities and staying at home principle. In most countries in West Africa the spread of the coronavirus continues to increase of which Ghana has recorded 408 cases with 8 deaths as at 11th April, 2020.

The Government of Ghana on $27^{\text {th }}$ march, 2020 announced the partial lockdown of two major cities in Ghana, Accra Metropolitan Area and Kumasi Metropolitan Area with about 7 million inhabitants which represent nearly a quarter of the total national population for a period of Two (2) weeks subject to review. This is a measure to help curtail the spread of the virus in the big cities, since it's seen as the hot spot for the diffusion of the virus among citizens.

This partial lockdown in the two major cities of Ghana is likely to have effect on access to social facilities in affected communities. It is based on this premise that this study seeks to assess the effects of lockdown of cities on the lives of urban poor to access social facilities in affected communities. The conventional literature is silent on the effects of total or partial lockdown on people access to social facilities, it is as a result of this, that this study seeks to bridge the knowledge gap. 


\section{Profile of the study areas}

The study covers two areas namely Accra Metropolitan Area and Kumasi Metropolitan area. Figure 1 show Accra Metropolitan Area in the national context while figure 2 show Kumasi Metropolitan area.

The Greater Accra Metropolitan area (GAMA) is a cosmopolitan with number of Metropolitan, Municipal and District Assemblies which is located between latitude $5^{\circ} 5^{\prime} 27^{\prime \prime} \mathrm{N}$ to $5^{\circ} 28^{\prime} 2^{\prime \prime} \mathrm{N}$ and longitude $0^{\circ} 4^{\prime} 58^{\prime \prime}$ to the east and $0^{\circ} 37^{\prime} 2^{\prime \prime}$ to the west along the Atlantic coast of Ghana (See figure 1). Greater Accra Metropolitan Area (GMA) has $53 \%$ urban population with $10.6 \%$ urban poverty rate (Cities alliances, 2017).

Fig.1. Map of Accra Metropolitan Area showing major towns.

Fig.2.Map of Kumasi Metropolitan Area

showing major towns.
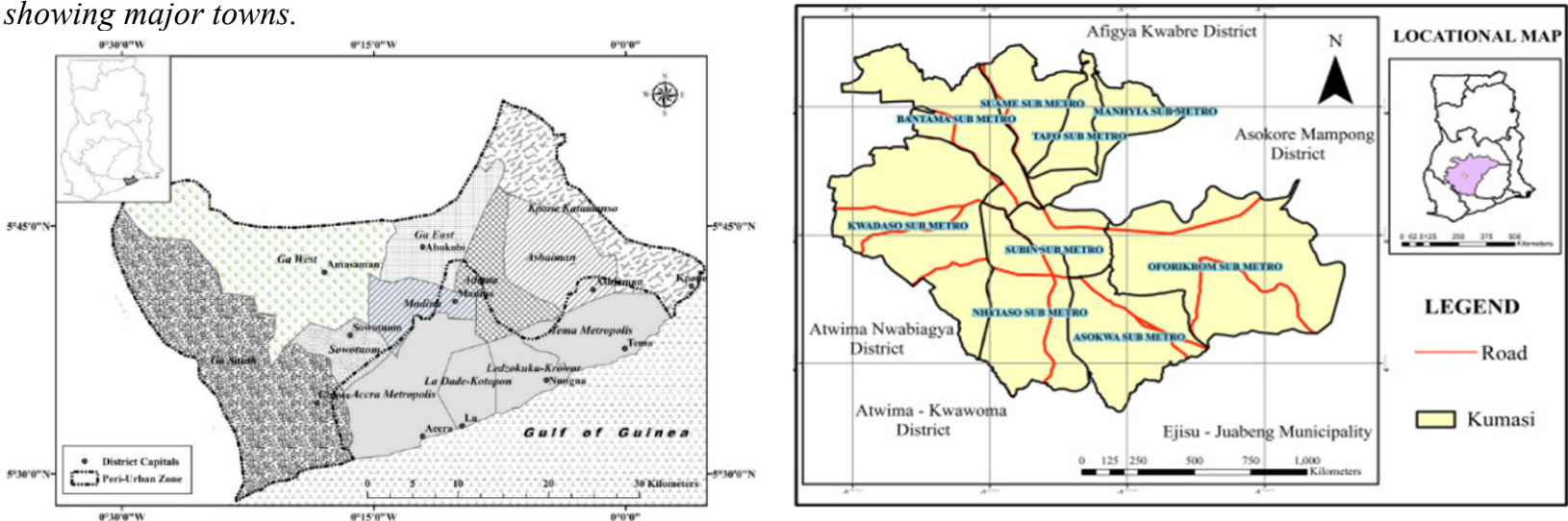

Source:(Amponsah et al, 2016)

Source :(Oduro et al., 2015)

The Kumasi Metropolis is located at the center of Ashanti Region of Ghana (See figure 2). Due to its centrally location makes it more accessible from all corners of the country. It is the second largest city in Ghana and It is projected that $48 \%, 46 \%$ and $60 \%$ of the Metropolis are urban, peri-urban and rural respectively. The Metropolis is about $\mathbf{2 5 4}$ kilometers; its physical structure is principally globular with a central located commercial area here is also number of satellite markets in the metropolis. These include Asafo Market, Bantama Market, Oforikrom Market and Atonsu Markets (Kumasi Metropolitan Assembly, (2019).

\section{Social Facility}

According to Yuliastuti and Purwoningsih (2018), Social Facility is facility established to provide social services for people living in a community. They further explained that social facility also provides space for societal interaction, values and cultural and added that these services include recreational service, medical service, Economic service and other services.

In another context social facility is seen as ancillary facility to hold and develop social, economic, and cultural of public life. It comprises of private, governmental and public school, service, health facilities, worship centers, commercial facilities, culture and recreation, and open space facilities. Correspondingly, in the work of Soefaat, (1997), the Kamus Tata Ruang, social facility is defined as systems or structures or buildings that deliver services to support community wants, which includes health, worship, and school. In the community context, Social facilities or community facilities are defined as buildings or structures possessed by government or the community used as public services, such as church, mosque, parks and green space (Soefaat, 1997). As the combination of hard and soft infrastructures, social infrastructures are meaningful to improve the quality of life of the community (Teriman \& Yigitcanlar, 2011).

\section{The nexus between outbreak of coronavirus pandemic lockdown and social facility}

The wide spread of Coronavirus in most African countries has led to government of most countries to put in measures that will help to curtail the spread of the disease. It was revealed that most case in African countries are from people who have travelling records, this means that most of the cases are import from overseas and only handful are community spread cases. However, government in Africa countries have taking the bull by the horn to adhere to the guidelines of the World Health Organization (WHO) to lockdown cities where there is rapid spread of the virus to ensure social distancing practice among citizens. African countries such as Lesotho, Mauritius, Rwanda, South Africa, Uganda, Zimbabwe, Botswana, Mozambique lockdown the entire country to ensure that the virus is not spread rapidly whiles Nigeria has lockdown only Three cities being Lagos, Ogun and Abuja which are seen as hot spot for the spread of the virus and Namibia and Ghana have lockdown 2 cities respectively. Ghana has lockdown its capital town Accra and the second largest city Kumasi to help contain the spread of the virus. The graph below highlights the number of days some African countries have lockdown their country or cities. Figure 3 revealed that Ghana has lockdown it's two cities for the period of 14 days (Two weeks). 
Figure 3 shows number days African Countries have lockdown their cities

$$
\text { No. of Days }
$$

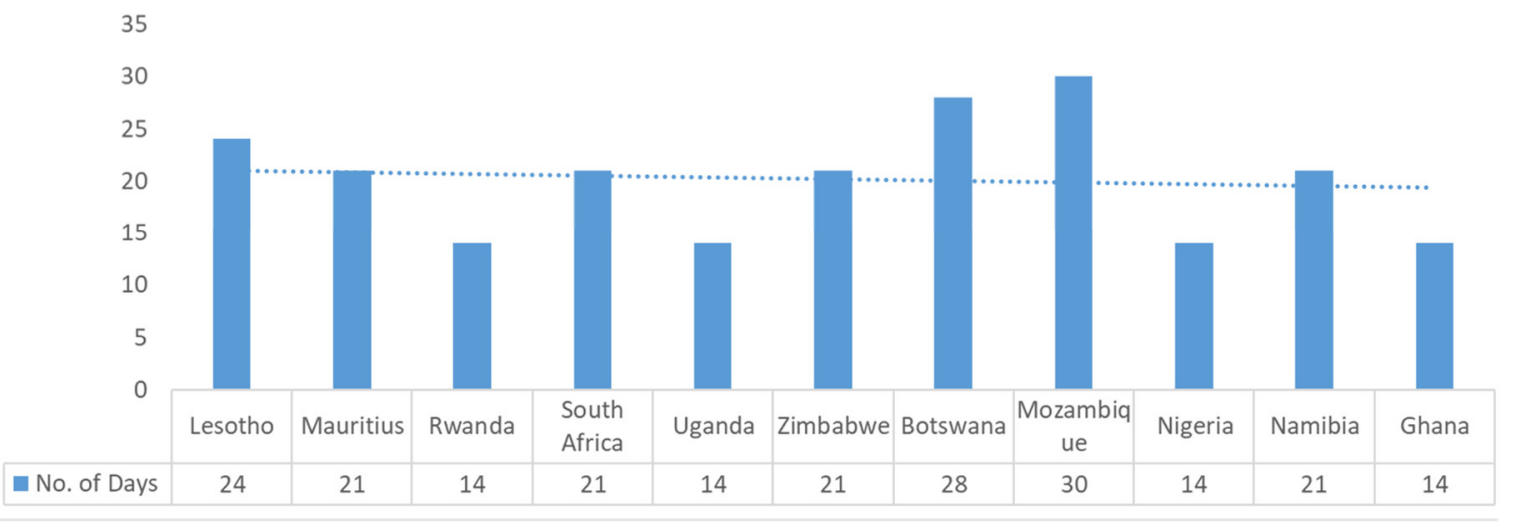

Source: BBC Africa, March, 2020.

However, this lockdown has effects on social facility which provides social, culture and economic services to the citizens of Ghana. According to Yuliastuti \& Widiastomo, (2015) community relations are measured using these four indicators: local institutions, neighbor relations, environmental security and social activities. They explained that social activities such as Muslims prayers, weekly community meetings, family welfare activities, mother and child health care makes the neighborhood unite and secure, but with this lockdown all these social activities will be out of place which will disunite family, friends and community.

Moreover according to Teriman et al., (2011), provision of social facility is to improve the quality of life, stability, equity and wellbeing of community members. They added that social facility is the pivotal for the development of society social capital and as such when people are denying access to these important facilities their wellbeing and social interaction will be jeopardies. This clearly explained that in Ghana whiles people in the city of Accra and Kumasi are lockdown, their access to social facility to improve their wellbeing and social interactions has been affected tremendously.

\section{Effects of COVID-19 Pandemic lockdown on Health facility}

According to World Health Organization (WHO) maternal death rate in Africa is so high that more than half a million of women die through pregnancy impediment every year, with regional maternal mortality ratio of 1000 per 100000 live birth. It was revealed that most of these death occur as a result poor access to health facility by pregnant women in Africa.

According to Stephenson et al., (2006), women who wants to give birth at health facility are those in urban communities whiles few give birth in their homes. They explained that individual household continue to access health facility base on religion, maternal age, education and among other factors. This clearly indicate that even though without lockdown, few people want to attend health care at the health facility and these has increase the number of maternal death in Africa, then with this two weeks' lockdown the willingness of pregnant women and sick people to access health care at health facility is questionable and these will increase the number of maternal death rate in Ghana and Africa at large.

According to Satistics South Africa Report (2011), majority of people who fall sick or get injured access health care at public health facility with the remaining few people relying on private doctor or family doctor. This is because its only handful of people in Africa who can have access to family or private doctor due to the high level of poverty. This suggest that the lockdown will deny majority of people from health care as a result of the restriction attached to movement within the lockdown cities and these might lead to loss of life.

People have to travel for longer distance before they will have access to health facility for health care (Stock, 1983). According to Ghana Television news report on April $8^{\text {th }}$, heavy security presence in affected communities has made it very difficult for some sick patients to come out to access medical care. This is likely to affect inhabitants in the affected communities who are seriously sick, most especially diabetes and hypertension patients. It is likely to ultimately worsen the health situation of some patients in the affected communities.

\section{Effects of COVID-19 Pandemic lockdown on Religious homes/places}

Ghana is a country dominated by religious population with majority of Ghanaians being Christians, thus $71 \%$ and $17 \%$ are Muslims (GSS, 2020). Religion is seen as way of life. According to Mutahhery (1977), in his book the "Rationality of Islam "religion is define as being "an all-round movement in the light of faith in Allah (God) and a sense of responsibility for the reformation of thoughts and beliefs, for the promotion of high principles of morality, 
establishment of good relations among members of society and the elimination of every sort of undue discrimination". According to Hammad (1990). A place of worship by Muslims is known as Mosque, it is also a public building, which is not only used for praying but for speeches, lecturing, teaching and training. He explained that Mosques are special spiritual place in the Islamic countries and added that their purposes have practically persisted unchanged for the past 14 centuries. This implies that people cannot do away with mosques where they perform their spiritual rituals, with lockdown in the city of Kumasi and Accra, Muslims who are known to be praying together will lose these spiritual meetings and gathering.

On the same hand, According to Filson, (2013), churches are believed to be the holy place to worship God by Christians. He expounded that When Christians wanted to meet for prayers, there is no place suitable for their needs except the church. Churches do not serve as place of worship but they serve as sites for the implementation of social service program among people (Brown et al., 2006). they added that churches were places used for political, social and economic reform in the $18^{\text {th }}$ century, which means that church facility is important to the life of Christians. The COVID-19 pandemic lockdown will affect the spiritual life both Christians and Muslims as they have been banned from meeting at mosques and churches to perform their spiritual rights.

\section{Effects of COVID-19 Pandemic Lockdown on Parks}

The COVID-19 pandemic lockdown is expected to affect the use of public space and parks in Kumasi and Accra, which is the engine for promoting social interactions and social cohesion. According to Peters, Elands, \& Buijs, (2010), parks and public spaces are used for meetings, gatherings and other social activities. They added that urban parks and public space aids social interactions, social cohesion and place attachment which can contribute to social gathering. Parks and space has the potential for promoting physical activity of people or community by providing opportunity to be active (Hecke et al., 2016). They added that people engaged in numerous activities at parks and these activities includes biking, walking, sitting and other vigorous intensive activities. It was revealed that people attached value to parks and space base on their ethnicity, tribe and culture (Özgüner, 2011). He explained that parks and spaces provide social, environment, physical and health benefits improving the life of urban dwellers. In this context the lockdown has affected the urban society from getting health benefits from parks where they can exercise.

\section{Effects of COVID-19 Pandemic Lockdown on School Facility}

Ghana education from Kindergarten to University has been closed as a result of the fear of the spread of Novel coronavirus among students by the president of Ghana. On $15^{\text {th }}$ march, 2020, the president Nana Addo Dankwa Akufo-Addo of Republic of Ghana gave an order that "All Universities, Senior High Schools, and basic schools, i.e. public and private schools, will be closed on Monday, 16th March 2020, till further notice". This implies that pupils and students will miss studies as a result of the closure of the schools and students who are preparing to sit for their Basic Education Certificate Examination (BECE) and West Africa Senior School Certificate Examination (WASSCE) will have difficulties to achieve their best. According to (Earthman, 2002), classrooms that have features and components such as good temperature, igniting and audibility have influence on the achievements of students. He indicated that students perform bad when studying in buildings where there is deficit of the said features. This explained that whiles students study in their homes, the likelihood of them not performing is high.

\section{Conclusion}

The paper assessed the effects of COVID-19 Pandemic lockdown on social facilities in Ghana. The study revealed that people in the urban centers depends on social facility to improve their health, wellbeing, education, fitness and also have the opportunity to socialized as well as engage in spiritual activities. Furthermore, the study showed that the novel Coronavirus pandemic lockdown would increase the number of maternal mortality death rate in Africa as a result of pregnant women having the fear of visiting the hospital with the mind of avoiding contracting the deadly virus at the health facility. Also, heavy security presence in lockdown communities has put fear in most residents who want to access health facilities which is likely to have negative repercussions on the lives of inhabitants in the affected communities.

\section{Recommendations}

Based on the findings discovered from the study, we recommend that the government and city managers should provide mobile clinic that will take care of pregnant women and other patients who have underlining sickness who cannot go to health facility to seek for medical attention as a result of the COVID-19 Pandemic lockdown. Again we recommend that families and community leaders should engage in social interaction through online platforms such as WhatsAPP, Skype and others. Moreover, we recommend that Government, Ministry of Education and Ghana Education Service should create online platform for Basic Education Certificate Examination(BECE) and West Africa Senior School Certificate Examination (WASSCE) candidates to undertake classes.

Furthermore, we recommend that parks and green space should be open for people to undertake exercise to 
keep the fit but they should practice social distancing to prevent the spread of the novel coronavirus among them. In the nut shell, we recommend that ministry of health and ministry of information should undertake serious public education and disseminate information on the need to access critical social facilities like hospitals when the need arise.

\section{Reference}

Africa, S.S. (2011), Use of Health Facilities and Levels of Selected Health Conditions in South Africa: Findings from the General Household Survey, 2011, Vol. 5.

Africanews,2020,https://www.africanews.com/2020/03/30/coronavirus-in-africa-breakdown-of-infected-virusfree-countries/. Accessed, 4/04/2020

Alexandra Peters, Pauline Vetter, Chloé Guitart, Nasim Lotfinejad, D.P. (2020), "Understanding the emerging coronavirus: what it means for health security and infection prevention", Journal of Hospital Infection, available at:https://doi.org/https://doi.org/10.1016/j.jhin.2020.02.023.

Amponsah, O., Vigre, H., Braimah, I., Schou, T.W. and Abaidoo, R.C. (2016), "The policy implications of urban open space commercial vegetable farmers' willingness and ability to pay for reclaimed water for irrigation in Kumasi, Ghana", Heliyon, Elsevier Ltd, No. 2, pp. 1-39.

Brown, D.R., Scott, W., Lacey, K., Blount, J., Roman, D. and Brown, D. (2006), "Black Churches in Substance Use and Abuse Prevention Efforts", Journal of Alcohol and Drug Education, available at: https://www.researchgate.net/publication/234613972_Black_Churches_in_Substance_Use_and_Abuse_Pre vention Efforts, Accessed, 9/04/2020.

City alliance (2017), Greater Accra Metropolitan Area (GAMA) - Cities Alliance

https://www.citiesalliance.org/sites/default/files/CB_Ghana_WEB.pdf, Accessed, 10/04/2020

Earthman, G.I. (2002), School Facility Conditions and Student Academic Achievement, California, available at:https://doi.org/,

Filson, F. V. (2013), "The Significance of the Early House Churches”, Journal of Biblical Literature, Vol. 58 No. 2, pp. 105-112.

Ghana Statistical Service, (2020), Ghana Population 2020 (Demographics, Maps, Graphs). https://worldpopulationreview.com/countries/ghana-population/ Accessed, 9-04-2020.

Hammad, R.N.S. (1990), "RASTI measurements in mosques in Amman, Jordan”, Applied Acoustics, Vol. 30, pp. $335-345$.

Hecke, L. Van, Cauwenberg, J. Van, Clarys, P. and Dyck, D. Van. (2016), “Active Use of Parks in Flanders ( Belgium ): An Exploratory Observational Study", International Journal of Environmental Research and Public Health Article, Vol. 14 No. 35, pp. 1-15.

John Hopkins Bloomberg School Of Public Health, 2020, COVID-19 daily update. https://myemail.constantcontact.com/COVID-19-Updates---April 9.html?soid=1107826135286\&aid=ejy6ab3zOD0, Accessed, 9/04/2020

Kumasi Metropolitan Assembly, (2019), Brief on KMA - Kumasi Metropolitan Assembly, $\mathrm{http}: / / \mathrm{kma} \cdot g o v \cdot g h / \mathrm{kma} /$ ?brief-on-kma\&page=5143, Accessed, 10/04/2020

Mutahhey, A. M (1997) 'Rationality of Islam', Islamic Seminary Publications, Accra

Nany Yuliastuti \& Yudhi Widiastomo. (2015), "Towards Better Social Housing Policy Based on Residents ' Satisfaction : A Case Towards Better Social Housing Policy Based on Residents' Satisfaction : A Case Study at Sendangmulyo, Semarang, Indonesia", Journal of Sustainable Development, Vol. Vol. 8 N0. No. August, available at:https://doi.org/10.5539/jsd.v8n2p149.

Oduro, C., Adamtey, R. and Kafui, O. (2015), "Urban Growth and Livelihood Transformations on the Fringes of African Cities: A Case Study of Changing Livelihoods in Peri-Urban Accra Urban Growth and Livelihood Transformations on the Fringes of African Cities : A Case Study of Changing Livelihoods in", Environment and Natural Resources Research, Vol. 5 No. 2, available at:https://doi.org/10.5539/enrr.v5n2p81.

Owusu, M., Annan, A., Corman, V.M., Larbi, R., Anti, P., Drexler, F., Agbenyega, O., et al. (2014), "Human Coronaviruses Associated with Upper Respiratory Tract Infections in Three Rural Areas of Ghana", PLoS ONE, Vol. 9 No. 7, pp. 24-27.

Özgüner, H. (2011), "Cultural Differences in Attitudes towards Urban Parks and Green Spaces, Landscape Research", Taylor \& Francis, Vol. 36 No. 5, pp. 599-620.

Peters, K., Elands, B. and Buijs, A. (2010), "Urban Forestry \& Urban Greening Social interactions in urban parks : Stimulating social cohesion?", Urban Forestry \& Urban Greening, Elsevier, Vol. 9 No. 2, pp. 93-100.

Pfefferle, S., Oppong, S., Drexler, J.F., Gloza-rausch, F., Ipsen, A., Seebens, A., Müller, M.A., et al. (2009), "Distant Relatives of Severe Acute Respiratory Syndrome Coronavirus and Close Relatives of Human Coronavirus 229E in Bats, Ghana”, Emerging Infectious Diseases, Vol. 15 No. 9, pp. 1377-1384.

Soefaat. (1997). Kamus Tata Ruang (First Edition). Jakarta: Directorate General of Human Settlements Ministry of Public Works Indonesia in corporation with Indonesian Association of Urban and Regional Planners. 
Stock, R. (1983), "Distance and the utilization of health facilities in rural Nigeria", Social Science \& Medicine, Elsevier, Vol. 17 No. 9, pp. 563-570.

Teriman, S., Yigitcanlar, T. and Mayere, S. (2011), "Social infrastructure planning and sustainable community: example from south east Queensland, Australia", Proceedings of the Business and Social Science Research Conference 2011, Dubai.

World Health Organization, 2020, COVID-19 Situation update for WHO Africa Region, external situation report 6. https://www.afro.who.int/health-topics/coronavirus-covid-19, Accessed, 9/04/2020

Yuliastuti, N. and Purwoningsih, P. (2018), "Utilization of social facility to reinforce social interaction in formal housing”, Nternational Journal of Architectural Research, Vol. 12 No. 1, pp. 134-151. 